\title{
Learned Societies and Academic Sociability in Nineteenth-Century Transylvania
}

\author{
Borbála Zsuzsanna Török \\ Zukunftskolleg / University of Konstanz, Department of History and Sociology
}

\begin{abstract}
Proceeding on sub-state and transnational scales, the study inquires into the cultural contextualization of those marginal territories of Europe whose participation in the larger circulation of knowledge and goods had faced prolonged infrastructural, economic, and political hindrances. The author seeks an answer to the question whether such regions with unusual social fragmentation, economic backwardness, and exotic external image do still belong to the "European" realm. Comparing the divergent trajectories of local learned societies in the eastern province of the Habsburg monarchy, Transylvania, she inquires into the correlation of scholarly practice and the formation of collective identities with regard to internal and external constitutive factors, and patronage and political support from the state (or the lack of it). The essay ends with a mixed result; local practices carried the peculiarities of the immediate environment, and also the impact of a Central-European, that is, Austrian, and German academic tradition. This locality could, and indeed, did occasionally look outlandish to native critics and foreign travelers. However, at least at the level of elite culture and scholarship, this province also shared the general traits of the "Western" practice.
\end{abstract}

\section{Keywords}

nationalism, public sphere, history of knowledge, Transylvanian historiography

The use of scholarship in the sociopolitical realm has figured prominently since Foucault, especially in relation to political power. It is a commonplace that already in the moment of its birth, enlightened science was not the "innocent creation, the product of reading, writing, and conversation, of amateur science and genteel amusements," but a new means of control over the physical and social realms. (Outram 1999: 32-40; Outram 2005: 39; Clark et al. 1999: 21-22; Munck 2000: 14). Much attention has been paid to the transfer and circulation of knowledge, its sites and institutions of origins, its trajectories, and the ways of its appropriation. These studies engage with the tension between the universalist claims of the social sciences since the Enlightenment, 
and the particularities ascribed by them to gender, social class, ethnic or racial belonging, and the unequal participation of these categories in the "realm of reason." Parallel to the recognition of Enlightenment's idea that "human nature" was best expressed in society, one is aware that "different kinds of humans partook of different kinds of social institutions." This perspective emphasizes that knowledge production is situated and bound to the environment, and the "material, instrumental, corporeal, practical, social, political circumstances" affect the cognitive results. This context sensitivity may even lead to the radical contestation of any universality: knowledge seems to be always local (Raj 2006: 9).

Locality does not designate only social but also geographical contexts. The editors of The Sciences in Enlightened Europe suggest that geographical location also has a transforming effect. In their somewhat tautological argument, the "provinces and peripheries" of the "European world," are those, where "cultural forces impinging from elsewhere" evoke local responses and local identification. Accordingly, transfer of knowledge since the eighteenth century from the Enlightened French-British "core" to the Mediterranean, Baltic and Germano-Skandinavian margins, resulted in the rejection of cosmopolitan universalism in favor of quasi ethnic localism, at the end of the eighteenth and the beginning of the nineteenth century (Clark, Golinski, Schaffer 1999: $31,310-311)$. In contrast to Europe's colonies, the history of these intraEuropean margins is still to be written. To what extent did they still belong to 'Europe,' and to what degree did they constitute Europe's exotic 'other' (Kontler 2006: 357-371; Shek Brnardić 2005: 147-178)?

My essay seeks to contribute to this inquiry by studying learned societies in the eastern province of the Habsburg monarchy, Transylvania. Looking at local adaptations of the German state sciences, i.e., Landeskunde (or Vaterlandeskunde, in Hungarian: honismeret), I too claim that scholarly practice was correlated with the formation of collective identities with regard to internal and external constitutive others. It carried the peculiarities of the local context, and also the impact of Austrian and German academic tradition. This locality could, and indeed, did occasionally look outlandish to native critics and foreign travelers. However, this province too shared the general traits of the "Western" practice.

Transylvania was an economically backward province without stable, locally funded institutions of higher learning and scholarship during the 18th and first half of the 19th century. Here the launching of scholarly institutions was a civic process, initiated by social elites. The divergent ethnic, cultural, and political allegiances shaped scholarship in a formidable way: learned 
sociability emerged within the geographical boundaries of ethnically distinct German, Hungarian, and Romanian milieus. On the other hand, these milieus regarded themselves as belonging to a larger transnational learned public.

There are two societies at the center of my study. The Transylvanian Saxon Verein für Siebenbürgische Landeskunde (Association for Transylvanian Regional Science, abbreviated as Landeskundeverein, 1842-1944) and the Hungarian Erdélyi Múzeum Egyesület (abbreviated as EME, Transylvanian Museum Society, 1857-1945) were the result of German and Hungarian initiatives to institutionalize and modernize scholarship. These projects were directly shaped or responded to competing political claims since the late 18th century. Examining the social context of the two savant societies, my essay assesses the civic ethos of scholarship and its ties with "definitions of belonging."

Ignored hitherto by historians of science, Landeskunde was immensely popular throughout the 19th century in the German-speaking realms of Europe, and was a rich field for identity construction on various scales, from the local to the European. Indeed, Landeskunde was framed by diverging (and conflicting) allegiances in estate ruled, multiethnic, and multidenominational Transylvania. Scholarly modernization did not bracket the traditional estatebased hierarchy but reconfigured it into a new, ethnocivilizational one. Despite their "modernizing" character and univeralist claims, scholarly practice recast the relations of inequality between the privileged and the unprivileged into differences between the learned and the unlearned, between the polished and the barbarian, and in ethnic terms, preparing the ground for future competing nation- and state-building in the region.

\section{Provincial Science at the End of the 18th Century}

The emergence of Landeskunde in Transylvania as a pronouncedly German science dates from the third quarter of the eighteenth century. Then the rationalization of administration demanded usable data on the peoples of the Empire and their environment. Scientific innovation was required to efficiently administrate the resources of the province and thereby increase the "public good." The chief initiator of improvement was the state. Nevertheless, in the second half of the century, there was growing interest in economic and social reform among the educated society. Learned societies were created to establish the methods suited for improving the material well-being of the state's subjects, mostly through enlightened Menschenbildung. In terms of rhetoric, this 
pedagogy targeted the accurate knowledge and thus the "humble love of the fatherland" (Sonnenfels 1977: 29-47; Csáky 1981: 172).

The scientific source of these activities was the empirical and descriptive German sciences of state. It was a loosely defined field that varied from university to university involving lectures in economics, statistics, finance, politics, police science (Polizeiwissenschaft, meaning roughly "public administration"), agriculture, forestry, mining, "technology," social policy, and sociology; its emphasis was not on "scientific method" or even an in-depth investigation of a particular subject, but on comprehensiveness and systematic knowledge of the state. Throughout the 18 th century, specialization was no priority, but rather the establishment of categories to describe the particularities of the socialphysical environment and the historical-legal development of the polity (Lindenfeld 1997: 14; Wolff 1721).

After 1750, state sciences expanded in the German universities: until the 1790s nine university chairs were established despite the general decline of higher education. The Catholic countries endorsed enlightened pedagogical ideas after the diminution of the Jesuits' role, and in the Habsburg lands cameralism, a variant of state science emphasizing the management of economy, became associated with the Theresian domestic reforms. It was a double process: the state enforced social discipline through centralization of authority, while a spreading civil society outside the boundaries of the state had an interest in cameralist sciences as well. Hence the growing number of reading societies after 1770 that had a keen interest in the Staatswissenschaften. These patriotic circles with university educated, mostly state employed constituency, had a great interest in general education and useful knowledge. What made the cameralist/state scientist classificatory mind suitable both to the expectations of the absolutist state and the emerging civic networks was its static vision on society, a notion of social equilibrium. It recognized an autonomous society based on talent that did not translate into an argument for social mobility (Lindenfeld 1997: 22-24, LaVopa 1986: 49-52).

This empirical scholarship was addressed in Transylvania by German speakers as Landeskunde or Vaterlandeskunde, and was concerned, in a similar fashion as its academic counterpart, with the details of local and regional conditions, building up an inventory of useful knowledge. Landeskunde assigned its field of operation at the local level, at most the regional level, collecting and disseminating information on political statistics, describing topography, mineral resources, weather, etc., with an emphasis on the particularities (Merkwürdigkeiten) of the fatherland (Schwartner 1798: 4). It was not 
present-centric, but integrated a historical perspective, whether antiquarian or constitutional-as established by the practice of well-known professors at the University of Göttingen, such as Gottfried Achenwall or A.L. Schlöser. In their vision history and statistics interconnected-"history is continuous statistics, and statistics is static history" - where history did not consist only of the biographies of kings or the chronicles of battles, but also their agriculture, commerce, and legal systems, that is, the very subjects of statistics (Schwartner 1798: 2-4).

The use of vernacular languages and the attachment to different geographical, linguistic, historical, and political traditions made Hungarian and Saxon venues form distinct although overlapping networks of communication. Transylvanian scholars and civil servants adopted the descriptive methods and meliorist outlook of state science as practiced at the University of Göttingen in linguistically separated circles. There were significant differences in the adaptations, though, depending on the host milieu. Landeskunde was more prolific among Saxon scholars, Hungarians published less and more fragmentarily in the two decades before and after the turn of the 19th century. Moreover, Saxon Landeskunde strove for an overall map of all the peoples of Transylvania, involving an exchange of Hungarian and Saxon specialists. In contrast to Saxon scholars, the encompassing regional aspect was weaker in Magyar honismeret, and the latter increasingly served projects of national emancipation in culture and implicitly in politics. Its narrower focus made it similar to the Romanian Şcoala Ardeleană (Transylvanian School), the latter initiating studies on history and language.

The emancipating character of Hungarian honismeret urged the self-assertion of the national elite via scholarship against the domination of a more advanced German culture. It also adopted the rhetoric of political self-assertion vis-à-vis Vienna, and competition with the perceived cultural and political superiority of Transylvanian Saxons. The more articulate the national standpoints became in politics by the turn of the century, the stronger was the entrenchment of the national perspective in Transylvanian scholarship. Somewhat pointedly formulated, the emergent Magyar national politics associated Hungarian honismeret more with the linguistic community, whereas Saxon Landeskunde intended to keep a more general focus on the whole fatherland.

The first Transylvanian learned journals reflected on the potential of a domestic reading public in comparison to the boom of learning and education in Germany, England, and France, establishing endurable patterns of comparison between the cultivated models and the circumstances at home. For both the Hungarians and Saxons, Protestant Germany emerged as the norm, 
with its universities and intellectual effervescence, to which the Transylvanian developments were measured. The diagnosis identified the reasons for insufficiencies in contrast to their superior neighbors (Neugeboren 1790: 1-27).

Some of these reasons, like the miserable prospects of regional scholarship, emerged from the economic and cultural political status quo. According to the Siebenbürger Quartalschrift, it is uniformity (Gleichförmigkeit) and a sense of community (Gemeinschaft) that form the basis of a sound public. There was still no central regional academy to coordinate regional scholarship. The linguistic, confessional, social, and educational fragmentation induced scepticism about the prospects of an integrated Transylvanian public. So the "cultural differences" among the Transylvanian "nations" were diagnosed as the main obstacle to the unfolding of public spirit. Geographical isolation, the troubled history of the province, its ethnolinguistic and religious differences and sensitivities were all considered to hinder the formation of an educated public. Indeed, when the Diet of 1790 discussed the plan of a provincial Hungarian academy, later modified into Erdélyi Nyelvmüvelö Társaság (Transylvanian Society for the Cultivation of Language), the argument went in favor of "national" (i.e., Hungarian) improvement through which the vernacular could be emancipated from a position of "oppression" and "contamination" with German.

The author, Daniel Neugeboren, classified the Transylvanian "nations" according to stages of education and improvement. The word "nation" was used here in the sense of a status group demarcated not only by confession and rank in the political system but also by a common language and history. Cultural refinement was related to the ability of the national tongues to serve as a vehicle of scholarly communication - an idea familiar both from politics (Joseph II) and the late Enlightenment German theorists of culture. In the following, the author asserted a civilizational hierarchy among the largest ethnic categories of the region, disregarding religion and rank in the feudal order.

The editors of the Quartalschrift did not advance cosmopolitan projects. They argued for region wide communication in their quality as members of overlapping German, Austrian, and Transylvanian cultural networks. Not lacking in gestures of fatherly condescendence towards the two other "nations," this stance committed itself to dynasty loyal Reichspatriotismus. The demand for German in public communication indicates the stance of Landeskunde advocates in the regional language strife. Transylvanian Saxon scholars understood their role as the most legitimate initiators of provincial improvement. This must be the reason why the scholarly focus as well as the target audience 
of the Quartalschrift transcended the narrow ethnocultural boundaries. The journal translated the writings of established authors of Landeskunde, reported on meetings of the Erdélyi Magyar Nyelvmivelö Társaság (Transylvanian Hungarian Language Society), as well as several learned societies abroad.

The focus remained on Saxon history, religion, and education, but there was interest in the Transylvanian Hungarian culture as well. Telling is the silence about Romanians - the practitioners of Landeskunde had little appreciation for the intellectual achievements of the emerging Romanian scholarship, and for its emancipating scope. Lucas Joseph Marienburg (1770-1821), author of a later treatise on Transylvanian Landeskunde, had only a contemptuous half sentence in regard to the "uncivilized Romanians" and their "foolish political attempts" (Marienburg 1987: 95). This was but a covert hint to Romanian attempts of political emancipation, received with the widespread aversion of the privileged Saxon minority (Heitmann 1998: 33-56). The articles on history centered on the feudal privileges of the Saxon estate, respectively the bliss and hindrances to the corporate freedom under various kings and governors. The history of the corporate nation was thus the dominant topic of this pragmatic account, a subject of chief political importance to the then contemporary Saxon public.

The insufficiency of Magyar in scholarly exchange, mentioned by Neugeboren in the Quartalschrift, was the most important concern of Hungarian scholars. The scholar Péter Bod (1712-1769) diagnosed as early as 1756 that "the Hungarian language has started to deteriorate quite much lately; it would be good to do something to embellish and strengthen it, as other nations do. It would be good to establish some Literata Societas, with members from Hungary and Transylvania." The plan was further elaborated by György Aranka and approved by the local Diet in 1790. But the topic was discussed also outside the political arena. An emerging Magyar-speaking public demanded education, not in German, but in the vernacular (Enyedi 1988: 9-39).

The argument is familiar. What is interesting is the widespread scepticism of German contemporaries, from Schlözer to the Transylvanian Saxon networks, towards the viability of Hungarian and the recommendation of German instead. It indicates how much political tension the vernacular movement precipitated. In his Kritische Sammlungen zur Geschichte der Deutschen in Siebenbürgen, Schlözer expressed his worries about the loss of German as an official language in the province. He feared the dissolution of a small linguistic minority within a sea of foreign tongued barbarians (Schlözer 1979: 662-663).

As the draft of a state sponsored academic institution focusing on the modernization of language did not receive permission from the Viennese 
Chancellery, its spiritus rector György Aranka founded two others. The first one was the previously mentioned Hungarian Language Society, the other was called Kézirások Társasága (Manuscript Editing Society). Both of them were private initiatives. In contrast to the Saxon project, Aranka thought in ethnic terms only, his addressee was not the whole Transylvanian but the national community. Here too Landeskunde, the knowledge of the fatherland, involved studies in natural science, statistics, and history (Aranka 1988: 71-101).

The more knowledge the state accumulated about its intellectual and skilled capital, the more effectively material culture could be administered and improved. Aranka noted that "this subject ... has little benefit concerning the society, but is of great utility concerning the patria, and it is the task of the noble Estates of the Land to publicize it, so that those who go abroad to study should be encouraged" (Aranka 1988: 71-101). During its thirteen years of existence, the encyclopedic interest in Transylvania's past and present led to the establishment of a natural science museum with a library of manuscripts, thanks to a network of supporters in Hungary, Vienna, and even at German universities.

After its cessation, the idea of a learned society was not forgotten. Repeated attempts were made at the following Diets to receive authorization for it. In the slowly growing Magyar-speaking public after the turn of the 19th century, the demand for such a cultural institution established itself as an indispensable requisite of "taste refinement" through education and increasingly the "national public spirit" and "national spiritual force." Later museum projects by Gábor Döbrentei (1785-1851), Farkas Sándor Bölöni (1795-1842), and others were related with the creation of a nationwide public sphere. (Kemény, Kemény 1841: 330-331)

\section{The Birth of a Socially Fragmented Public}

The study of learned societies is inextricably bound to the theme of academic sociability, a term that links the history of academic disciplines with the social locales of their manifestation. This approach was shaped by Norbert Elias's vision on the "civilizing process," that posited the reformation of manners in the salon a key aspect of Enlightenment. Also, the study of the public realm received a significant impetus from Jürgen Habermas' classical study on publicity, linking the sites of liberal critique with the logic of the market and the bourgeois society. Since then, clubs, societies, academies, and learned circles have been regarded as the sites of the private exercise of reason (Clark, Golinski, Schaffer 1999; Outram 2005). 
In the Hungarian context, the study of voluntary associations has been linked more to the theme of civic self-organization than to academic sociability. In the 1980s, this theme was particularly important in regard to dissidence under communism (Arato, Cohen 1999). Later this approach was adopted by social historians who inquired into the formation of the middle class in nineteenth-century Hungary. Recent writings share the assumption that the study of associations is instrumental to addressing large social phenomena such as middle class formation in nineteenth-century Hungary. Local studies on voluntary self-organization documented urbanization and economic modernization. (Kövér 1991; Halmos 1994; Lengyel 1988; Gyáni, Kövér 1998; Tóth 1998). But the study of civil mobilization also emerged in relation with democracy and self-government. These writings reflect the influence of Jürgen Habermas' public sphere without, however, addressing its limitations and the problems of its applicability in the Central-Eastern European context. (Fenyö 1993; Gyáni 1991).

The Habermasian concept of public sphere, a chronologically evolving model of sociability and communication, which proceeds in time from apolitical literary and scientific activity to discussion about politics, is well known. Its subversive nature lies in its revolutionary way of communication, based on reason only, independent of the social status of the speaker. Its principle is therefore inclusive: membership should not be based on rank but on education and familiarity with matters of "common concern." The theoretical value of the model is indisputable; its ability to bring seemingly disparate areas under a single approach has inspired a great amount of scholarship, linking discourses on the private realm with those of government, the communicative practices of voluntary associations with social structures and political institutions (Van Horn Melton 2001: 10).

What is then the problem with it? One of the shortcomings, noticed by historians, was its underlying vision of society. Van Horn Melton for instance pointed out the anachronistic class teleology inherent in the Habermasian model, arguing that the public sphere was not the pool only of the (economically prosperous) bourgeoisies congregating in class struggle "to burst the bonds in which absolutism and a feudal order had shackled it" (Geoff Eley 1992: 288-399; Habermas 1992: 421-461). It is true that the nascent public sphere in Western Europe involved quite much of the "middling sort." But even there the membership involved substantial numbers of nobles. And as far as the non-nobles are concerned, research in France and Germany demonstrated that they were less of the middle-class professions, but rather those (university professors, high status officials, and pastors) tied more to the state, that fostered public debates. One observes the social intermingling of very 
different social categories, contributing thus to the formation of a new elite by the integration of the propertied and/or educated, who created new criteria of social distinction and exclusion through education and taste. The liberalizing networks of exchange washed away in the Western societies the limitations between noble and non-noble, and at the same time reinforced the distance between propertied (and educated) and plebeian (and lacking education) (Eley 1996; Munck 2000:14-17). Reconsiderations like these have been of great relevance for research in East-Central Europe, where the social composition of the emerging public sphere is quite heterogenous, and involved a considerable amount of nobles.

Habermas and many of his followers saw the modern public sphere as strictly bound to the Enlightenment epicenters in France, England, and Scotland, and "other relevant parts of Protestant Europe," especially the Northern parts of the German-speaking lands. These spheres were centered in the prosperous urban environment of Paris, London, Hamburg, and other cities, whereas Southern and Eastern Europe, including the Habsburg Empire, could at most hope for "eventually provid[ing] an interesting ground for comparison" (Habermas 2001). It is easy to imagine where a province like Transylvania belongs on this map. Here, the ethnoconfessional inequalities of the urban social structure, the gap between the towns and the ethnically different countryside, created indeed serious barriers to regional public communication. These social cleavages were further compounded by the nationalist identity politics of the 19th century. The larger towns had predominantly Hungarian and German character, and the urban middle classes and bureaucracy as well. This structure did not change significantly until World War I. The largest ethnic constituency, the Romanians, was overwhelmingly rural, and became socially mobile only in the second half of the 19th century. ${ }^{1}$ Their intellectual and professional elite did not play a central role in the major Magyar and Saxon urban self-government, and kept their ties to the village. This ethnodemographical segmentation shaped tremendously the emerging civic networks. In the 19th century the cultural associations were one facet of a diversifying town-based network, unfolding primarily on the basis of ethnic and denominational affiliation, and only secondarily if at all on an occupational, ideological, or other basis.

1) The census of 1900 counted ca. 233,000 Germans, 815,000 Magyars, 1,397,000 Romanians and 32,000 other nationalities on the territory of Transylvania $\left(57,804 \mathrm{~km}^{2}\right)$. The great majority of the Transylvanian population was rural ( $81.8 \%$ in $1869,76.5 \%$ in 1890 and $70.8 \%$ in 1910). Livezeanu, 1995: 138. 
According to Munck, public debate in Southern and Eastern Europe lagged well behind that of the northwest. He names the grounds as "restraints of tradition, state-backed religious conservatism, far lower literacy rates, persistence of censorship controls abandoned or unenforceable in the northwest, absence of explosive economic growth which loosened social barriers, facilitated consumer spending, raised expectations and spawned genuine liberalization in northwestern Europe in the century before the French Revolution" (Munck 2000: X). The emergent voluntary associations were indeed no seedbeds of liberal critique in the Habermasian sense. Censorship hindered the emergence of free speech before the Reform Era in the 1830s and 1840s (Orosz, Pölöskei 1994; Lengyel 1988; Péter 1998: 148-186; Halmai 1990). Nevertheless their educational and savant programs involved elements of reform. Improvement, to which the associations subscribed, was interpreted in national terms which did acquire political edge already towards the end of the 18th century with the beginning of governmental language policies. The issue of education in the vernacular language would be further politicized with the emergence of intra-Transylvanian claims of Hungarian political domination in the Reform Era.

Feminists criticized the Habermasian model for an underlying masculinist assumption of the public sphere. (Landes 1988; Fraser 1986: 31-56; Young 1986: 57-76; Ryan 1990). Indeed, coming from an earlier tradition of Marxism, the author left the topic of gender unreflected. But as Habermas himself pointed out, the widespread male exclusivity of the liberal public can be explained as a discrepancy between its principle and praxis. On the other hand, the reproaches are often selective, and focusing only on (violent forms of) women's exclusion (Clark et al. 1999: 25; Van Horn Melton 2001). Van Horn Melton goes for a middle way, according to him the legacy of public sphere is ambiguous, being "neither inexorably emancipatory, nor inherently repressive," neither "irredeemably masculisist," nor "unqualifiedly feminist." According to my observation, male exclusivity tended to be context specific. Even in the case of the two examined Transylvanian associations, one finds different patterns, a more inclusive Hungarian aristocracy-dominated one and a more male dominant Saxon Bildungsbürger type. But all in all, my case study supports the less optimistic evaluations of gender cleavages to the disadvantage of women, and sees them as personages of reduced role in the public, and no entrance at all to formal politics. And that was the case in Transylvania not only in the eighteenth but also during the nineteenth century.

The national aspect of the "ideological template," similar to that of gender, is disregarded in the study of Habermas as a private issue, and hence of no legitimate place in the liberal public. The fact that identity claims (national, 
religious, gender, or class related) do affect explicitly or implicitly the public deliberation is a later recognition, and came to the fore first in the early nineties with the American reception of the Strukturwandel. In recent interpretations, the public sphere is no longer the space of debates "about an already established common good" but rather a field "for the clarification ... and constitution of interests," a fragmented territory of discursive connections organized around political agendas, should they pursue national or other goals (Calhoun 1992: 35).

\section{Nationality and Academic Sociability at the Turn of the Century}

The discourse of voluntary associations and attendant social practices from the 18 th through the 19th century can be understood as a common European and transatlantic phenomenon. Transnational associative sociability is indeed regarded as a "case of entangled history that crosses national boundaries and challenges nation-state paradigms" (Hoffmann 2003a: 275; Hoffmann 2000). Its Tocquevillian principle is rooted in the republican concern with the social and moral basis of politics, that is, with the "constitution of souls" as formed by the polity.

Stefan-Ludwig Hoffmann contends that "from Boston to Saint Petersburg" there was a shared belief originating in the Enlightenment that sociability led to "mutual improvement, for increasing our knowledge and mending our heart." Freemasons were among the first great practitioners of sociability across the continent in the 18th century who created the link between private virtues and common good. Their tendency to create new social cleavages by admitting nobles and non-nobles alike and distinguishing them from the "common people," has been regarded as the capacity to generate new elites. Hence the newer interpretations of the lodges as "places of social compromise." Similar to the debates on public sphere, these perspectives emphasize commonalities instead of the differences between the territories on both sides of the Atlantic, at least on the analytic level. In Hungary and Transylvania, as well, freemasonry emerged during the 1770s among the aristocracy, and these circles were as dedicated to Josephist religious tolerance as they embraced initially the enlightened reform program of the Emperor (Balázs 1997: 72, 270-279).

Contemporary learned journals from Transylvania reflect a heightened appreciation for the scholarly career, but also an awareness of its unfavorable domestic circumstances. The ideal intellectual is the typical Aufklärer in the service of his country. That does not mean bureaucratic enslavement but, quite the contrary, "inviting and motivating" the state to support scholarship. Such 
a scholar is a public man with an impact on his "nation and time." Educated sociability went beyond the limits of institutionalized learning. The examples had been set by a number of well established Masonic lodges, with their keenness on self-formation that gradually extended into plans for the cultural improvement of the entire society. Monarchy wide, the lodges were immersed in questions about the interrelated nature of individual virtues and the public good, the love of homeland in relation to the love of mankind, and the aims of education. They sought cultural and moral improvement in a framework of a new type of sociability, establishing "sites of social compromise" between different social classes of educated men (Jacob 1991: 72). These exclusive circles involved members of the aristocracy, the higher nobility, high office bearers from the provincial government, and the crème of the intellectual elite. In Transylvania as well, between the cycles of control and persecution, the $1780 \mathrm{~s}$ witnessed a bourgeoning of Masonic life involving the most remarkable patrons (governors, such as Baron Samuel Brukenthal, founder of the first private museum in Transylvania, and Count György Bánffy, patron of the first Transylvanian learned society) and scholars of various ethnic background. The concern of Neugeboren and his fellow patriots was similar to those of their German counterparts: the constitution of a national public beyond the narrow circle of learned men, via shared language and (regional) culture. ${ }^{2}$

Far from revolutionary ideas and within the range of the contemporary idiom, the Transylvanian learned men advocated the safe path of improvement. Social discrepancies could be meliorated, he argued, if all the inhabitants acquired proper knowledge about their Vaterland. The task was "making the Fatherland acquainted with itself; turning its attention to important truths (facts)" concerning its "moral," "political," "scholarly," and "economic" aspects through writings on geography, natural history, "morality of its [Transylvanian] inhabitants once and now," "pragmatic perusals of history," and also literary reviews and news of "important events of our times." This would be the ground for "private and public happiness" (Neugeboren 1790: 25).

All voluntary associations, with their roots in the same civic culture as the lodges, inherited these principles. They had existed already in mid-eighteenthcentury Central Europe and, similar to the lodges, came to suffer in the repressive post-revolutionary climate, and again after the Congress of Vienna. In the first decades of the 19th century they were the assemblies for new elites across

2) See the project of the Popularphilosophen in Prussia to constitute the national public without the limitations of social rank and status by promoting "the culture of our Vaterland" (Bollenbeck 1994: 32). 
the continent, which represented and legitimized their social and political purposes. Their plans of education/Bildung and charity and other humanitarian scopes were integrated into the large programs of liberal reforms, and were seen by contemporaries as conducive to the ideal of civil society or, as the Germans referred to it, bürgerliche Gesellschaft.

Such plans of civil society/bürgerliche Gesellschaft were present in the Hungarian-Transylvanian Reform Era as well. As László Péter argued, here the notion of polgári társadalom was coined in the pre-revolutionary era, designating the political program of the liberal nationalists. Polgári társadalom meant the opposition to the contemporary feudal distinctions between the estates (at places synonymous with barbarism), to the sharp differentiation between the estates and the serfs living in bondage, and to the discrimination between religions and languages. It aimed to replace a heterogeneous and fragmented legislation with a unitary law applicable to everyone. Contemporary liberal plans of civil society aimed to eventually create an educated and politically empowered citizenry. According to György Kövér, civil society is not the direct correspondent but an interpretation of the Hungarian term polgárosodás (closest to Verbürgerlichung), the latter acquired from the noun polgárság, an inflected form of polgár, i.e., "city dweller." It was created at the beginning of the 19th century as a metaphrase from the German Civilisation, denoting cultural and moral refinement. By that time the universal norms of the late Enlightenment were reinterpreted in terms of a national cultural (and linguistic) progress, partly adopting the German paradigm, and partly contesting the widespread Germanization of the state administration in the Habsburg Monarchy. A second significant meaning of polgárosodás refers to citizenship, the elevation of the unprivileged to the protective heights of constitutional rights. Much later than the previous two meanings, economic reference (i.e., appartenance to the middle class) was also absorbed by the term (Péter 1998: 156-158; Gergely, Veliky 1974: 5-42; Kövér 1991: 44).

How was the program of civil society linked with those of the learned societies? Is the scholarly agenda of the Verein für Siebenbürgische Landeskunde and the Eredélyi Múzeum Egyesület to be seen in relation to emerging regional plans of civil society? The parallel emergence of these societies is inexplicable without the existence of shared discourses such as the one of civil society, respectively of the norms and practices of public exchange in the lodges, voluntary associations, museums, and the printed media. These were present in traditional societies such as the one in Transylvania, marked by deep social cleavages. Their establishment in the remote region of the Monarchy should not be considered as isolated and accidental edifices of the national geniuses as 
the national traditions in historiography suggest, nor as creations of national elites struggling against a repressive regime.

These institutions were in principle public, open to everyone, and adhered to the modern norms of sociability and exchange, even if this principle was selectively applied in the regional context. An often heard critique to the Transylvanian academic and cultural institutions, especially of the Landeskundeverein, the EME, and the Asociația Transilvană Pentru Literatura Română şi Cultura Poporului Român (Transylvanian Association for Romanian Literature and the Culture of the Romanian People, ASTRA, 1861), is their ethnic exclusivity. Understanding the nature of contemporary exchange between socially and geographically separated groups helps explain exactly this gap between the intended goals of cooperation of these institutions and the everyday practice of ethnocultural separation.

Practice, resulting from the sociocultural background of the agents of civil society, brought out the differences. It sounds today commonsensical that not only in the crown lands of the Austrian Monarchy but throughout the continent claims to the abstract common good had been linked already in the Enlightenment to conflicting national perspectives (Hoffman 2003: 273; Péter 1998: 158). Not only the new political elites but the clienteles of the associations interpreted education and Bildung in ethnocultural terms. This is also visible in the practice of the Transylvanian cultural associations: their initial encompassing program as well as the stated social openness had a regional and European scope. In actuality they served the identity politics of their national clientele.

Founded by the provincial elites, comprising professors, high ranking state functionaries, and ecclesiastics, both associations had encompassing cultural programs which targeted the exploration of the province in the European context. They intended to "discover" the hitherto "ignored" or "barely known" Transylvanian territory, as well as the history and conditions of its peoples for the benefit of their respective national publics. These rather general claims were affected by national politics as it emerged since the end of the 18th century. Hungarian plans of civil society envisaged the creation of the nationstate, demanding the union of the province with Hungary in opposition to the centralizing policy of the Habsburg Empire, and supporting the improvement of the Hungarian language and culture connected to the national integration of the non-Magyar ethnicities into the national polity. In contrast, the Transylvanian Saxon politicians and intellectuals mistrusted the union and the centralizing policies of the would-be nation-state. Saxon improvement too 
advocated a new cultural identity, which was simultaneously regional and Protestant German. This combined with the traditional loyalty to the Imperial dynasty, with emphasis on regionality and ethnic diversity, and constituted a counterbalance to the Hungarian national liberal agenda.

The sociability of the early 19th century, moral improvement, Bildung, emulation, and belief in civic virtue, combined with conflicting political agendas. This contributed greatly to the development of a nationally fragmented public life in Transylvania, similar to other multiethnic provinces of the Empire. On the eve of the revolution of 1848, Saxons, Hungarians, and Romanians had separate associational networks in the larger towns. These cleavages remained constant with the proliferation of the civic realm in the second half of the century. The maintenance of Church autonomy and schooling under ecclesiastic tutelage after 1867 played obviously a significant role in Transylvania where linguistic and religious boundaries roughly coincided in the case of the three great ethnic populations. After the failure of the 1848 revolution, Hungarian scholarly sociability received the ideological traits of political resistance. It was also at this time when civic institutions were often viewed as substitutes for the missing state infrastructure. This quasi political rhetoric brought the $E M E$ in its initial years a broad public support. The same rhetoric characterizes Saxon civic activism during the Compromise, and the Landeskundeverein, with its publications, textbooks, and public events, became its chief mouthpiece.

The EME and the Landeskundeverein emerged from the civic blueprints of the late 18th and early 19th century. They had a reduced number of educated clientele recruited from the political and ecclesiastic elite and the higher state administration. Social historians have shown that exclusive circles of this kind encountered difficulties in the second half of the 19th century. Some of them were structural: after the upheavals of 1848, civic life showed tendencies of democratization. Throughout Europe and America, ever broader social strata established their own associations. Women made increasingly their presence in the public sphere as well, although in East-Central Europe this was far from overturning the traditional order. They founded associations adequate to their expected role as nurturers and subordinates, supported charity related and religious scopes. The new wave, which reached Transylvania in the relaxing climate of the 1860s, was motivated less by the lofty Bildung related and humanitarian ideas of the earlier decades, but was dedicated to more pragmatic scopes. The new associations pursued mostly profit (see the trade associations after the abolishing of the guilds), special interests (recreational, 
vocational, etc.), and professional goals. ${ }^{3}$ The transnational dynamics of the "sociable society" experienced another explosion from the 1880 s to the advent of World War I, when civic activism became a strategy for politically-oriented social movements and started integrating the countryside. In Hungary too the new currents of mass politics, social democracy, and populist nationalists discovered the associations as means to organize the peasant and urban lower-class society (Szabó 2003). The modification of sociability, the socialprofessional fragmentation, but even more significantly the radicalizing nationalisms adopting its institutional form, were the phenomena that brought Europe-wide the "crisis of the moral vision of a society built on associations" (Hoffmann 2003a: 292). In Transylvania, the learned societies founded in the early decades of the century found themselves in a deficit of legitimacy at the end of the nineteenth century.

How did they react to the professional and ideological challenge? Hungarian historiography considered cultural and educational associations as agents of national mobilization and, in the case of non-Hungarians, of cultural resistance against the illiberal and nationalizing government (Schödl 1995: 269; Szarka 1995). Several nineteenth-century educational institutions became platforms of nationalist agitation. Here belonged also the state supported Magyar organizations, like the Erdélyi Magyar Közmüvelödési Egyesület (Transylvanian Hungarian Educational Association, EMKE) whose scope was the linguistic Magyarization of the ethnic diaspora. The largest network was built however by the Felvidéki Magyar Közmüvelödési Egyesület (Hungarian Educational Society of Upper Hungary, 1882), the Erdélyi Magyar Közmüvelödési Egyesület (Transylvanian Hungarian Educational Society, 1885), and the Dunántúli Közmüvelödési Egyesület (Transdanubian Hungarian Educational Society, 1890).

The Landeskundeverein maintained its learned character and remained under the tutelage of the intellectual, ecclesiastic, and political elite. It intensified cooperation with German and Austrian academies. However, when it came to the politically sensitive issue of nationalities, it yielded to völkisch nationalism; the genre of political pamphlets with a sharper nationalist, occasionally social Darwinist, tones emerged in the publications. The President, Friedrich Teutsch, legitimized them saying that "politics used historical weapons ... and the border between history and political essay is difficult to draw, or is impossible altogether" (Teutsch 1889: 643). Bishop Teutsch even

3) Maurice Agulhon described the trend as "multiplication, diversification, and liberalization" (Agulhon 1978: 13-18). 
welcomed the 'political turn' and hoped that beyond uncovering the "laws of being," these writings "shaped the will" of the reader. He regarded scholarship as the means for "developing our national consciousness."

The encouragement of the populist tone went hand in hand with advocating dilettante work, the latter defended as the corollary of minority existence. To be a savant was a luxury, argued Teutsch, and since the standard members of the Saxon learned society were mostly gymnasium professors and pastors, they worked under poorer conditions than their German (and Hungarian) counterparts" (Teutsch 1889: 684-686). The populist rhetoric undervalued the academic achievements of the society-by that time the society was corresponding with more than one hundred academic institutions in Europe and America, a number never achieved by its Transylvanian Hungarian counterpart (Teutsch 1889: 684-686; Jahresbericht des VSL 18791880: 25-33).

While the Landeskundeverein was firmly embedded into a Saxon network of civil associations, the $E M E$ traveled on a different route. Its career in Dualist Hungary is an outstanding example of how the institutions of the privileged nationality profited from governmental support. After the formal unification of Hungary and Transylvania, the country's second university was established in Cluj/Kolozsvár in 1872, symbolizing both "national emancipation and unity" in the new state, and the integration of nationalities and harmonization of the eastern geographic region. Since the university brought better prospects of research thanks to ministerial subsidies, benefiting mostly a Hungarianspeaking academic clientele, the $E M E$ played no small part in shaping the character and future faculty of the university. The alliance with the University of Kolozsvár launched a period of unforeseen professional innovation from above. The $E M E$ gradually became the university's research institution, and its structure changed entirely by the end of the century (Erdélyi 1942: 54).

In a similar fashion to the Landeskundeverein, the EME too became increasingly specialized by the turn of the century, dividing its activity between research and popularization, reaching out thus to the nonprofessional urban audience. Also, the $E M E$ itinerary meetings displayed a sharply nationalist rhetoric. Lajos Shilling for instance asserted at a public lecture in Târgu Mureş/ Marosvásárhely in 1906 that the state had the duty to support substantially the association to help Hungarians in their competition with the 'nationalities': "Our museum can fulfill its modern destination only through the common effort of the society and the state ... Our leading Hungarian race would not need to blush that the handful of Saxon people managed to create a museum without state support, which is in many respects ahead of us" 
(Schilling, 1906: 9-11). The event brought 332 new enrollments, which more than doubled the number of active members.

If the tone towards the Saxon fellow institution was competitive, it turned clearly hostile towards Transylvanian Romanians. The exclusive contributor on Romanian matters for the $E M E$ periodicals, university professor Gergely Moldován, famous for his apologies of Hungarian nationality politics, and regarded as a renegade among the Romanian intelligentsia for the same reason, condemned the "tendentious intentions of Romanian historiography," the "tale of Dacian continuity and its falsifications," and agitated against the Romanian irredenta (Moldován 1895, 1896, 1904). Moldován also contributed with valuable comparative ethnographic descriptions of the Transylvanian Romanians to the $E M E$ periodical. Still it is noteworthy that while both the Saxon and Hungarian institutions spent considerable effort on writing their own national histories, Romanians were represented in their journals in the genre of ethnography, which widened the contrast between the scholarly selfimage of the 'historical' nations and the one of the compatriots 'without history.' That such a stance disregarded (in the Hungarian case) or was hypercritical (in the Saxon case) towards works on Romanian history and philology authored by their compatriots and from the Romanian Kingdom, is understandable from the intransigence of contemporary state-supported Hungarian nationalism. However, it is highly symptomatic that Moldován's writings date from a period of unprecedented political mobilization among Transylvanian Romanians, a mobilization that was as intense and multifaceted in its political-intellectual options as it valorized historiography in order to put forward the social and political emancipation of the "most blatantly disregarded" nationality (Szász: 686).

\section{Conclusion}

The Transylvanian case study illustrates how scholarship and its institutional framework were affected by the modernization of education and the public realm in the second half of the 19th century. The national polity in post-feudal Hungary encouraged the development of specialized and differentiated educational and civic infrastructures. It abolished the vestiges of the regional traditional order, and contributed to social homogenization. However, the nation-state introduced new inequalities between the privileged Hungarian 'titular' nation and the national minorities. Ethnic differences were upheld by the legislation that did not erase but cemented previous forms of national 
antagonisms. The incentives of cultural homogenization in the two to three decades before World War I led to the final alienation of intraregional ethnonational perspectives, as illustrated through the examples of the two associations under scrutiny. The path divergences were also sustained by structural and functional differences. The range of activities, the material and human resources, the degree of institutional modernization, and existing contacts to regional institutions (such as the university, church, or schools, even the selection or ignorance of particular topics of study) had a decisive role to play in this process.

This development was not determined by the government alone. Civic society itself went through a fundamental transformation. Also, here the sociocultural assets played a crucial role in the prevailing of ethnic differences. In general, civic networks became socially accessible, they covered now all the urban areas and spilled over to the countryside. Their neo-humanist goals from the Reform era, with an emphasis on Bildung, improvement, and emulation, were increasingly replaced by other more pragmatic and specialized scopes. In this situation, the lofty educational claims of older, more traditional, and socially exclusive institutions had difficulties of adjustment. The solutions chosen by the Landeskundeverein and its Hungarian counterpart illustrate the different strategies. The first sought to integrate itself into the Saxon public sphere and appropriated the stance of the political elite. The $E M E$, on the contrary, lost its ties with the civic society and became increasingly dependent on the state and adopted its aggressive national rhetoric. But the degree of identification with external perspectives depended also on established social practices. In contrast to the predominantly male and ethnoreligiously homogenous Landeskundeverein, the EME preserved its relative openness towards Jews and women from the higher ranks of society.

The nationalization of the region closed a process of ethnocultural differentiation which replaced the archaic, polyethnic, and federative outlook of the Ancien Régime with competing nationalisms, as illustrated by the history of the two institutions. The development was far from linear if one thinks of the consecutive phases of absolutism and then détente at the end of the 18th century, conservative restoration and then renewed liberal impetus in the first half of the 19 th, followed by another neo-absolutist shift after the revolution of 1848 , and finally, the establishment of the liberal polity with its illiberal turn by the beginning of the 20th. The long-term perspective makes more visible the nationalisms 'at work,' as shaped by the contingencies of state-building politics acting against local hegemonies and sociopolitical structures. The conflict-ridden relation between the state and society had a fundamental influence also on the development of the public sphere, on plans of civil society, and actual 
codifications of citizenship. In my opinion, these are the chief ingredients of the enduring national canons in culture and scholarship.

Revisiting thus the 'classical' models of the public sphere, the question is less whether there was a liberal or enlightened public sphere in Transylvania, that is, whether plans of civil society traveled as far as the region. Rather one should ask about the specific social context of these plans, and the mechanism of interrelated and conflicting ethnic loyalties in the composite Habsburg Monarchy, to understand the nature of ethnically segmented public spheres. One has to consider competing and mutually exclusive plans of improvement as framed by conflicting political agendas. The national plans of civil society were the result of continuous self-reflection and self-comparison to the politically relevant (and often threatening) social other. Within the province the competing perspectives measured themselves with each other but they were conditioned principally by relevant external centers.

In the polycentric field of national identification, the local and regional power struggles were significant. In a comparison with the ethnicization of associations in the western areas of the Monarchy, such as Moravia or Bohemia, one finds similar patterns of behavior. Gary B. Cohen's study illustrated how old guard German liberals in Prague claimed to represent the interest of the entire ethnic community while struggling to keep their leading position in an increasingly inclusive and diverse civil society. Pieter Judson's conclusion on the anti-liberal movements in Austria is applicable to Hungary and Transylvania as well: "the gradual and ongoing integration of new social groups into the Bürger polity was bound to weaken the tight hold that the liberal elites had traditionally exercised over local social and political life through their positions in the voluntary associations" (Judson 265; see also Csáky 1981; Mannová 1992; Mannová 1999). As the divergent trajectories of the two Transylvanian learned societies illustrate, state support played an equivocal role in this process. While in general it contributed to social and economic modernization and the educational boom in the second half of the long 19th century, its selective and discriminating intervention deepened the existing ethnosocial cleavages.

\section{Bibliography}

Agulhon, Maurice. "Vers une histoire des associations." Esprit 6 (1978): 13-18.

Aranka, György. "Egy Erdélyi Magyar Nyelvmívelő Társaság felállításáról való rajzolat az Haza Felséges Rendjeihez." [Plan addressed to the Estates of the fatherland about establishing 
a Transylvanian Hungarian Language Society] In Aranka György erdélyi társaságai, [The Transylvanian societies of György Aranka] edited by Enyedi, Sándor, 42-68. Budapest: Szépirodalmi Könyvkiadó, 1988.

—. "A Magyar Nyelvmívelő Társaságról újabb elmélkedés." [Another thought about the Transylvanian Hungarian Language Society] In Aranka György erdélyi társaságai, [The Transylvanian societies of György Aranka] edited by Enyedi, Sándor, 71-101. Budapest: Szépirodalmi Könyvkiadó, 1988.

Arato, Andrew, and Cohen, Jean. "Civil Society and the Public Sphere." In Civil társadalom, forradalom és alkotmány. Budapest: Új Mandátum, 1999.

Az Erdélyi Muzeum Egyesület bölcselet-, nyelv-és történelemtudományi szakosztályának kiadványai [The publications of the philosophy, language and historical sections of the EME] IX-XXII (1892-1905). Edited by József Szinnyei (IX), József Szinnyei and Lajos Szádeczky (X), Lajos Szádeczky (XI-XXII).

Balázs, Éva H. Hungary and the Habsburgs 1765-1800. Budapest: Central European University Press, 1997.

Bollenbeck, Georg. Bildung und Kultur. Glanz und Elend eines Deutungsmusters. First edition. Frankfurt: Insel Verlag, 1994.

Calhoun, Craig. Habermas and the Public Sphere. Cambridge, MA: MIT Press, 1992.

Clark, William, Golinski, Jan, and Schaffer, Simon. "Introduction," In The Sciences in Enlightened Europe, 3-31. Chicago: University of Chicago Press, 1999.

. "Provinces and Peripheries, Introduction." In The Sciences in Enlightened Europe, 307-312. Chicago: University of Chicago Press, 1999.

Cohen, B. Gary. The Politics of Ethnic Survival: Germans in Prague, 1861-1914. Princeton: Princeton University Press, 1981.

Csáky, Moritz. Von der Aufklärung zum Liberalismus. Studien zum Frühliberalismus in Ungarn. Vienna: Verlag der Österreichischen Akademie der Wissenschaften, 1981.

Eley, Geoff. "Nations, Publics, and Political Cultures: Placing Habermas in the Nineteenth Century." In Habermas and the Public Sphere, edited by Craig Calhoun, 288-399. Cambridge, MA: MIT Press, 1992.

Enyedi, Sándor, ed. Aranka György erdélyi társaságai [The Transylvanian societies of György Aranka]. Budapest: Szépirodalmi Könyvkiadó, 1988.

Erdélyi Múzeum. Kiadja az EME. A bölcsészet-, nyelv-, és történettudományi szakosztály, az Erdélyi Nemzeti Múzeum könyvtára, érem-és régiségtára közlönye [Transylvanian Museum, bulletin of the philosophy, language and historical sections of the $E M E$, the library, the numismatics and archeological collections of the National Museum] XXI-XXXI (1906-1914) new series, edited by Pál Erdélyi.

Erdélyi, Pál. Emlékkönyv az Erdélyi Múzeum-Egyesület félszázados ünnepére 1859-1909 [Memorial volume in honor of the half century anniversary of the Translyvanian Museum Society]. Kolozsvár/Cluj: EME, 1942.

Fenyő, István. "A hazai liberalizmus forrásvidékeiről." [On the sources of Hungarian liberalism] Kortárs 37, no. 3 (1993): 99-102.

Fraser, Nancy. "What's Critical about Critical Theory?" In Feminism as Critique: On the Politics of Gender, edited by Sheila Benhabib and D. Cornell, 31-56. Minneapolis: University of Minnesota Press, 1986.

Gergely, András. “A 'civil társadalom' hazai irodalmából." [From the domestic literature on civil society] Politikatudományi Szemle no. 1 (1993): 171-182. 
Gergely, András, and János Veliky. "A politikai közvélemény fogalma Magyarországon a XIX. század közepén." [The concept of political public opinion in Hungary in the middle of the 19th century] In Magyar Történelmi tanulmányok VII, [Hungarian historical studies, vol. VII] edited by Fehér András, 5-42. Debrecen, 1974.

Gündisch, Gustav. "Der Verein für Siebenbürgische Landeskunde. Eine Wissenschaftsgeschichte." In Wege Landeskundlicher Forschung. 25 Jahre Arbeitskreis für Siebenbürgische Landeskunde, 1962-1987. Cologne: Böhlau, 1987.

Gyáni, Gábor. "'Civil társadalom’ kontra liberális állam a XIX. század végén.” [“Civil society” versus liberal state at the end of the 19th century] Századvég no. 1 (1991): 145-155.

Gyáni, Gábor, and Kövér, György. Magyarország tárdadalomtörténete a reformkortól a második világháboruig. [The social history of Hungary from the Reform Era until World War II] Budapest: Osiris, 1998.

Habermas, Jürgen. "Further Reflections on the Public Sphere." In Craig Calhoun, Habermas and the Public Sphere, 421-461. Translated by Thomas Burgher. Cambridge, MA: MIT Press, 1992.

Halmai, Gábor. Az egyesülés szabadsága. Az egyesülési jog története. [The freedom of association. The history of the right of association] Budapest: Atlantisz Kiadó, 1990.

Halmos, Károly. "Magyarországi polgárosodás. Tallózás az 1988-1992 közötti történeti irodalomban" [Bourgeoisification in Hungary. A selection of historical literature from 19881992] Aetas no. 3 (1994) 95-154.

Heitmann, Klaus. "Die Rumänen Siebenbürgens aus deutscher Sicht im 19. Jahrhundert," In Das Bild des Anderen in Siebenbürgen, edited by Konrad Gündisch, Wolfgang Höpken, and Michael Markel, 33-56. Cologne: Böhlau, 1998.

Hoffmann, Stefan-Ludwig. "Democracy and Associations in the Long Nineteenth Century: Toward a Transnational Perspective." Journal of Modern History 75, no. 2 (2003a): 269-299.

—. Die Politik der Geselligkeit. Freimauerlogen in der deutschen Bürgergesellschaft, 1840-1918. Göttingen: Vandenhoek \& Ruprecht, 2000.

- Geselligkeit und Demokratie. Vereine und zivile Gesellschaft im transnationalen Vergleich 1750-1914. Synthesen. Probleme europäischer Geschichte vol. 1. Göttingen: Vandenhoek \& Ruprecht, 2003 b.

Jacob, Margaret C. Living the Enlightenment. Freemasonry and Politics in Eighteenth-Century Europe. New York: Oxford University Press, 1991.

Judson, Pieter M. Exclusive Revolutionaries. Liberal Politics, Social Experience, and National Identity in the Austrian Empire, 1848-1914. Ann Arbor: The University of Michigan Press, 1996.

Kemény, József, and Kemény, Sámuel. “Tekintetes Karok és Rendek!” [Honored Estates!], In Az Erdélyi Nagyfejedelemség s hozzá vissza kapcsolt Részek három nemes Nemzeteiből álló Rendeinek Kolozsvár szabad királyi várossában 1841-ik Év November 15-ik napján kezdődött Ország Gyülésökről készített Jegyző-Köny, [Protocol about the Diet of the three noble estates of the Transylvanian Duchy and the re-annexed Parts, held in the free royal town of Kolozsvár, begun on November 15, 1841] 330-331. Kolozsvár, 1841.

Kontler, László. “Introduction. What is the (Historians') Enlightenment Today?” European Revue of History — Revue Européenne d'Histoire 13, no. 3 (2006): 357-371.

Landes, Joan. Women and the Public Sphere in the Age of the French Revolution. Ithaca: Cornell University Press, 1988.

LaVopa, Anthony. Grace, Talent and Merit. Cambridge: Cambridge University Press, 1986. 
Lindenfeld, David F. The Practical Imagination. The German Sciences of State in the Nineteenth Century. Chicago: The University of Chicago Press, 1997.

Livezeanu, Irina. Cultural Politics in Greater Romania. Regionalism, Nation Building and Ethnic Struggle, 1918-1930. Ithaca: Cornell University Press, 1995.

Lowood, Henry E. "Science for the Fatherland," In Patriotism, Profit and the Promotion of Science in the German Enlightenment, 205-261. New York: Garland Publishing, 1991.

Makkai, László. “A kolozsvári kir. Ferenc József Tudományegyetem történelme 1872-1919.” [The history of the Ferenc József University, 1872-1919] In Erdély Magyar egyeteme, [The Hungarian university of Transylvania] 153-185. Kolozsvár, 1941.

Mannová, Elena. "Intoleranz in Vereinen, Vereine in intoleranter Umgebung." In Ethnokulturelle Prozesse im Gross-Staedten Mitteleuropas. Bratislava: Narodopisy ustav, Slovenska akademia vied, 1992.

—. Marienburg, Lucas Joseph. Geographie des Grossfürtstenthums Siebenbürgen. Reprint, Vienna: Böhlau Verlag, 1987.

Moldován, Gergely. "Nyílt levelek a bukaresti román kulturális liga elnökéhez," [Open letters to the president of the cultural leagues of Bucharest] Erélyi Múzeum (1895): 38-39.

—_. "Román kérdés-magyar nemzetpolitika," [Romanian question-Hungarian national politics] Erélyi Múzeum (1895): 40-44, 450, 512, 561.

_. "A román nemzetiségi törekvések," [The Romanian national movements] Erélyi Múzeum 7 (1896): 392-394.

"Magyar-szász szövetség," [Hungarian-Saxon coalition] Erélyi Múzeum (1904): 431.

Munck, Thomas. "The Enlightenment," In The Enlightenment. A Comparative Social History 1721-1794, (1-20). London: Arnold, 2000.

Neugeboren, Daniel. "Über die Lage und Hindernisse der Schriftstellerei in Siebenbürgen," Siebenbürgische Quartalschrift 1 (1790): 1-27.

Orosz, István, and Pölöskei, Ferenc, eds. Nemzeti és társadalmi átalakulás a XIX. században Magyarországon. [National and social transformation in 19th century Hungary] Budapest: Korona Kiadó, 1994.

Outram, Dorinda. "The Enlightenment Our Contemporary," in The Sciences in Enlightened Europe, edited by William Clark, Jan Golinski, and Simon Schaffer, 32-40. Chicago: University of Chicago Press, 1999.

— . "Coffee Houses and Commoners," In The Enlightenment, 11-27. Cambridge: Cambridge University Press, 2005.

Péter, László. "Volt-e magyar társadalom a XIX. században? A jogrend és a civil társadalom képződése" [Was there a Hungarian society in the 19th century? The order of law and the formation of the civil society]. In Az Elbától keletre. Tanulányok a magyar és kelet-európai történelemböl, [East of the Elba. Studies in Hungarian and East-European history] Péter, László, 148-186. Budapest: Osiris, 1998.

Raj, Kapil. "Introduction," In Relocating Modern Science. Circulation and Construction of Scientific Knowledge in South Asia and Europe. Seventeenth to Nineteenth Centuries, 1-26. Delhi: Permanent Black, 2006.

Ryan, Mary. Women in Public. Baltimore: Johns Hopkins University Press, 1990.

Schilling, Lajos. "Az Erdélyi Nemzeti Múzeumról," [About the Transylvanian National Museum] In Az EME Marosvásárhelyt, 1906 jünius 4-5 napján tartott elsö vándorgyülésének évkönyve, [Memorial volume of the first EME itinerary congress held in Marosvásárhely on June 4-5, 1906] 6-12. Kolozsvár, 1906. 
Schlözer, August Ludwig. Kritische Sammlungen zur Geschichte der Deutschen in Siebenbürgen. 1795-1797. Reprint, Cologne: Böhlau, 1979.

Schödl, Günther, ed. Deutsche Geschichte im Osten Europas. Land an der Donau. Berlin: Siedler Verlag, 1995.

Schwartner, Martin. Statistik des Königreichs Ungern. Ein Versuch von Martin Schwartner, Professor der Diplomatik, und erstem Bibliothek-Custos auf der Kön. Ungrischen Universität zu Pest. Pest: Matthias Trattner, 1798.

Shek Brnardić, Teodora. "Intellectual Movements and Geopolitical Regionalization. The Case of the East European Enlightenment." East Central Europel L'Europe de Centre-Est. Eine wissenschaftliche Zeitschrift 32, no. 1-2 (2005): 147-178.

Szabó, Miklós. Az újkonzervativizmus és a jobboldali readikalizmus története, 1867-1918. [The history of neoconservatism and right-wing radicalism, 1867-1918] Budapest: Új Mandátum, 2003.

Szarka, László. Szlovák nemzeti fejlödés - magyar nemzetiségi politika 1867-1918. [Slovak national development - Hungarian nationality politics, 1867-1918] Pozsony: Kalligram, 1995.

Teutsch, Friedrich. "Unsere Geschichtsschreibung in den letzten zwanzig Jahren, (1869-1889)" Archiv für Siebenbürgische Landeskunde 22 (1889): 619-687.

Tóth, Árpád. "A társadalmi szerveződés rendi és polgári normái. A Pesti Jótékony Nőegylet fennállásának első korszaka," [The feudal and bourgeois norms of social organization. The first era of the Women's Charity Association in Pest] FONS 5, no. 4 (1998): 411-479.

Önszervezö polgárok. A pesti egyesületek társadalomtörténete a reformkorban. [Self-organizing citizens. The social history of voluntary associations in Pest in the Reform era] Budapest: L'Harmattan, 2005.

Van Horn Melton, James. The Rise of the Public in Enlightenment Europe. Cambridge: Cambridge University Press, 2001.

"Verzeichnis der Akademien, Vereine und Gesellschaften, mit welchen der VSL in Verbindung steht, sammt Angabe der im gegenseitigen Schriftentausche gewechselten Druckwerk." In Jahresbericht des Vereins für Siebenbürgische Landeskunde, 1879-1880, 25-33. Hermannstadt, 1881.

von Sonnenfels, Joseph. Der Mann ohne Vorurtheil. Cited in B. Becker-Cantarino, "Joseph von Sonnenfels and the Development of Secular Education in Eighteenth-Century Austria." In Facets of Education in the Eighteenth Century, edited by James A. Leith, 29-47. Oxford: Voltaire Foundation, 1977.

Wolff, Christian. Vernünftige Gedanken von dem gesellschaftlichen Leben der Menschen, und insonderheit dem gemeinen Wesen. Halle, 1721.

Szász, Zoltán. "Political Life and the Nationality Question in the Era of Dualism (1867-1918)." In History of Transylvania. Vol. III. From 1830 to 1919, editor of the English translation Kovrig, Bennett, 635-746. Columbia University Press, New York, 2002.

Young, I. M. "Impartiality and the Civic Public." In Feminism as Critique: On the Politics of Gender, edited by Sheila Benhabib and D. Cornell, 57-76. Minneapolis: University of Minnesota Press, 1986.

Zimmermann, Harald. "Bemerkungen zur Geschichte des Vereins für Sebenbürgische Landeskunde." In Studien zur Geschichtsschreibung im 19. und 20. Jahrhundert, edited by Paul Philippi, 24-53. Cologne: Böhlau, 1967. 